\title{
Nursing and midwifery research activity in Arab countries from 1950 to 2017
}

Waleed M. Sweileh ${ }^{*}$, Huda Abu-Saad Huijer², Samah W. Al-Jabi ${ }^{3}$, Sa'ed H. Zyoud ${ }^{3}$ and Ansam F. Sawalha ${ }^{1}$

\begin{abstract}
Background: Nursing and midwifery research activity is an important indicator of the quality of healthcare services and the status of nursing profession. The main aim of this study was to assess the research activity in nursing and midwifery field in Arab countries.

Method: The current study implemented bibliometric method using Scopus database. The search strategy used country affiliation or journal name or keywords as a strategy to retrieve the required documents. The study period was from 1950 to2017. Analysis included a presentation of bibliometric indicators and VOSviewer mapping of the retrieved data.

Result: 2935 documents were retrieved making up less than 1\% of global nursing and midwifery research output. Of the retrieved documents, 25\% were published in high rank (first quartile $=\mathrm{Q} 1$ ) journals. The majority (56.7\%) of the retrieved documents were published in the last five years of the study period. The retrieved documents received an average of 6.9 citations per document with an $h$-index of 47 . The total number of authors who took part in publishing the retrieved documents was 10,572, giving an average of 3.6 authors per article. Jordan ranked first in research output. Researchers from Jordan took part in over than one third (1023; 34.9\%) of the retrieved documents. Lebanon (35.5\%) ranked first in the percentage of documents published in Q1 journals. The United Arab Emirates ranked first in the percentage (67.4\%) of publications with international authors. The most active journal involved in publishing nursing research from Arab countries was Life Science Journal (158; 5.4\%). The University of Jordan was the most productive institution while the American University of Beirut ranked first in the percentage (36.9\%) of documents published in Q1 journals. Author keyword analysis and10 most cited articles showed that non-communicable diseases and nursing education were the focus of nursing research in Arab countries.
\end{abstract}

Conclusions: Nursing and midwifery research activity in Arab countries has dramatically increased especially over the past five years. Despite this, nursing research is still in its infancy, lagging in quantity and quality compared to developed countries.

Keywords: Nursing, Midwifery, Bibliometric analysis, Arab countries

\section{Background}

The growing role of nurses and midwives in the provision of healthcare services and the growing burden of both communicable and non-communicable diseases have created an urgent need of many trained, knowledgeable, and skilled nurses who rely on scientific evidence in their daily practice [1-5]. In response to this need of skilled nurses and midwives, many Arab

\footnotetext{
* Correspondence: waleedsweileh@yahoo.com

'Department of Biomedical Sciences, College of Medicine and Health

Sciences, An-Najah National University, Nablus, Palestine

Full list of author information is available at the end of the article
}

countries started new nursing education programs including graduate and specialized nursing programs. The increased number in nursing programs in Arab countries helped in meeting the increasing demand for nursing profession. However, research output remains an important indicator of the progress in nursing profession and the quality of healthcare services in any country $[6,7]$.

Bibliometric analysis is a method used for quantitative and qualitative assessment of research activity in any field [8-11]. Bibliometric analysis is used to generate

C The Author(s). 2019 Open Access This article is distributed under the terms of the Creative Commons Attribution 4.0 International License (http://creativecommons.org/licenses/by/4.0/), which permits unrestricted use, distribution, and 
indicators of the excellence and professional development. Several bibliometric studies have been published on nursing research. For example, a very recent bibliometric study about global research output on nursing was carried out [12]. A second example, a bibliometric study about robotics used to assist or augment nursing care was published [13]. A third example is a bibliometric study carried out to address the characteristics of the research utilization literature in nursing field [14]. A fourth example is a bibliometric analysis to visualize the impact of nursing research in which the authors illustrated the importance of bibliometric methodologies to explore the richness of nursing research [15].Up to the authors' best knowledge and based on a literature review, no bibliometric analysis of nursing and midwifery research in Arab countries had been published. Therefore, the aim of the current study was to analyze research activity in the nursing and midwifery field in Arab countries. Health policymakers, educators, clinicians, and researchers will benefit from the current bibliometric study in identifying how to direct research funding and how to allocate budgets for future development of nursing profession. Assessment of nursing research activity will motivate researchers and create a nursing research alliance in Arab countries that serves to promote nursing profession, education, research, and healthcare services in Arab countries. The current study is in line with recommendations and future strategic planning of the World Health Organizations (WHO) regarding developing nursing and midwifery research and profession in the Middle Eastern region [16].

\section{Method}

\section{Database used}

In the current study, SciVerse Scopus was used to retrieve the required literature. Scopus is Elsevier's abstract and citation database launched in 2004. Scopus covers nearly 22,794 active titles from over 11,000 publishers, in life sciences, social sciences, physical sciences and health sciences [17]. The use of Scopus was based on the advantages it has over other databases which make it suitable for such studies [18]. For example, Scopus is the largest database in terms of the number of indexed journals. Scopus is $100 \%$ inclusive of Medline and larger than Web of Science [18]. Scopus database is suitable for bibliometric studies because it facilitates bibliometric analysis of the retrieved literature.

This study was carried out using bibliometric methodology, which differs from scoping reviews or systematic reviews. In bibliometric analyses, retrieved documents from a single database are analyzed [19, 20]. In contrast, systematic reviews have a specific research question to be answered using a few publications [21, 22]. For scoping reviews, it is a preliminary assessment of potential size and scope of a certain research literature, including ongoing research, and aims to identify nature and extent of research evidence $[23,24]$.

\section{Search strategy}

In this study, all Arab countries recognized by the Arab league were included. There are 22 Arab countries, which differ in the number of population, income, and healthcare system [25]. However, Arab countries share a common language and, to a large extent, common history and cultural standards. The list of the 22 Arab countries recognized by the Arab league differs from those defined by World Health Organization (WHO) as Eastern Mediterranean Region (EMRO), which includes 19 Arab countries besides Iran, Afghanistan, and Pakistan. The list of Arab countries includes Egypt, Kingdom of Saudi Arabia, United Arab Emirates, Qatar, Kuwait, Bahrain, Yemen, Jordan, Palestine, Syria, Iraq, Palestine, Lebanon, Tunisia, Morocco, Algeria, Sudan, Somalia, Mauritania, Djibouti, and Comoros.

In the current study, nursing research activity was defined as documents that fit one of the following three criteria. First, any document published from any school/ college/faculty/department of nursing in any Arab country. Second, any document published in any nursing/ midwifery journal with at least one author affiliated with any Arab country. Third, any document published in any journal and has a nursing-related keyword in the title, with at least one author affiliated with any Arab country. Nursing keywords used in the third criterion include "nursing", "nurse", "midwife", "midwives", "birth attendant", and "childbirth" at home". The third criterion was used to minimize false-negative results that might be missed by the first and second criteria. The keywords used were those derived from the word nursing or midwife. The study period was from January 01, 1950 to December 31, 2017. Data analysis was performed on the same day to avoid errors due to citation dynamics with time. No approval of the ethics committee was sought for the current study since no humans or human materials were involved. The search strategy with the keywords used is shown in Additional file 1.

\section{The validity of the search strategy}

In the current study, the research strategy was validated using methods stated in the previously published bibliometric studies [26-30]. The absence of false-negative results was confirmed by comparing two different methods of data collection; data obtained by the search strategy were compared with data available in Scopus for the selected active authors. For example, suppose that one of the active authors was Professor X and that the number of documents assigned to this author was 50 based on the bibliometric strategy. We searched Scopus 
for the number of documents of $\mathrm{X}$ using author search methodology. We did the same for the remaining authors in the top ten active list and the numbers obtained by the two methods were compared. Interclass correlation was used to assess the extent of agreement between the two methods [31-35]. The list of active authors used to test for validity was shown in Additional file 2. An excellent agreement between the two methods with an interclass correlation above $95 \%$ and a $p$-value less than $5 \%$ indicates a high validity of the search strategy. In the current study, the interclass correlation was $97 \%$ and $p$-value was $<0.01$.Two of the coauthors, S.Z and A.S, carried out the validation process. A third author (W.S) intervened whenever there was disagreement between the two authors regarding any document.

For the absence of false-positive results, three authors (S.Z, S.A and A.S) reviewed the title and the abstract of the top cited 500 documents and excluded any falsepositive results. Some false-positive results include documents about plants and cell cultures as well as nursing animals. The total number of false-positive results removed was 31 articles.

\section{Bibliometric indicators and mapping}

In the current study, both quantitative and qualitative indicators were presented. Quantitative indicators included types of documents, languages encountered in the retrieved literature, annual growth pattern, ten most active countriesstratified by Gross Domestic Product (GDP) per capita [36], ten most active journals, ten most active authors, ten most active institutions, and most frequently encountered author keywords presented as network visualization map. VOSviewer software was used for mapping [37]. This software is a free program available from Leiden University [38]. In the visualization maps, author keywordsare presented as nodes. Larger node size indicates a higher frequency of occurrence of a particular keyword.Network visualization map was also created for international collaboration. The thickness of the connecting line between any two countries in the collaboration map indicates the strength of collaboration [39]. The node size in the map is a relative presentation of the research output of the country. In VOSviewer maps, a minimum of 10 occurrences was used as a threshold. No keywords were omitted from the map.

Qualitative indicators included citation analysis, most cited documents, journal rank, and Hirsh index ( $h$ index) which is an indirect measure of readership and the extent of interest of other researchers in the document(s) being cited [40-44]. For citation analysis, no exclusion of self-citations was made. The rank of each journal was obtained from SCImago Journal Rank (SJR) website [45]. The SCImago Journal raking is a publicly available portal that includes the journals and country scientific indicators developed from the information contained in the Scopus ${ }^{\bullet}$ database (Elsevier B.V.). Quartile rankings $(\mathrm{Q})$ were derived for each journal according to which quartile of the SJR distribution the journal occupies for the assigned subject category. Q1 denotes the top 25\% of the SJR distribution, Q2 for middle-high position (between top 50\% and top 25\%), Q3 middle-low position (top $75 \%$ to top $50 \%$ ), and Q4 the lowest position (bottom $25 \%$ of the SJR distribution).

\section{Result \\ Research output}

The search strategy yielded 2935 journal documents. The total number of nursing and midwifery publications obtained from Scopus using the same method was 5,133, 097 documents in peer-reviewed journals. Therefore, the contribution of Arab countries to nursing and midwifery field was less than $1 \%$. One hundred and six (3.6\%) research articles received funding from non-Arab funding agencies or institutions.

The retrieved documents were research articles (2664; $90.8 \%)$ and review articles (161; 5.5\%). In addition, there were $57(1.9 \%)$ letters and notes, $25(0.9 \%)$ editorials, 13 $(0.4 \%)$ full conference papers, $6(0.2 \%)$ short surveys, and $9(0.3 \%)$ of an unknown type at the time of analysis. The vast majority of documents were in English (2914; 99.3\%).The retrieved documents were published in journals indexed within the subject areas of medicine (1394; $47.5 \%)$, nursing (1383; 47.1\%), and social sciences (192; $6.5 \%$ ) with the certain overlap among subject areas.

\section{Most frequent author keywords}

Visualization of author keywords showed that most frequent author keywords existed in five clusters (Fig. 1). The first cluster (red) included cancer-related keywords, quality of life, mental health, and Lebanon. The second cluster (green) included keywords related to knowledge, attitudes, barriers, nursing students, Saudi Arabia, and Egypt. The third cluster (light purple) included keywords related to job satisfaction of nurses. The fourth cluster (light green) included keywords such as breast cancer, prevalence, and risk factors. The fifth cluster (light blue) included keywords such as Saudi Arabia, nurses, and nursing education.

\section{The 10 most cited articles}

The retrieved documents received 20,107 citations, including self-citations. The average number of citations was 6.9 citations per document. The $h$-index of the retrieved documents was 47 . The documents that received the highest citation was a systematic review published in $B M C$ Geriatrics [46].The second highly cited article was published in The Lancet and was about the potential role 


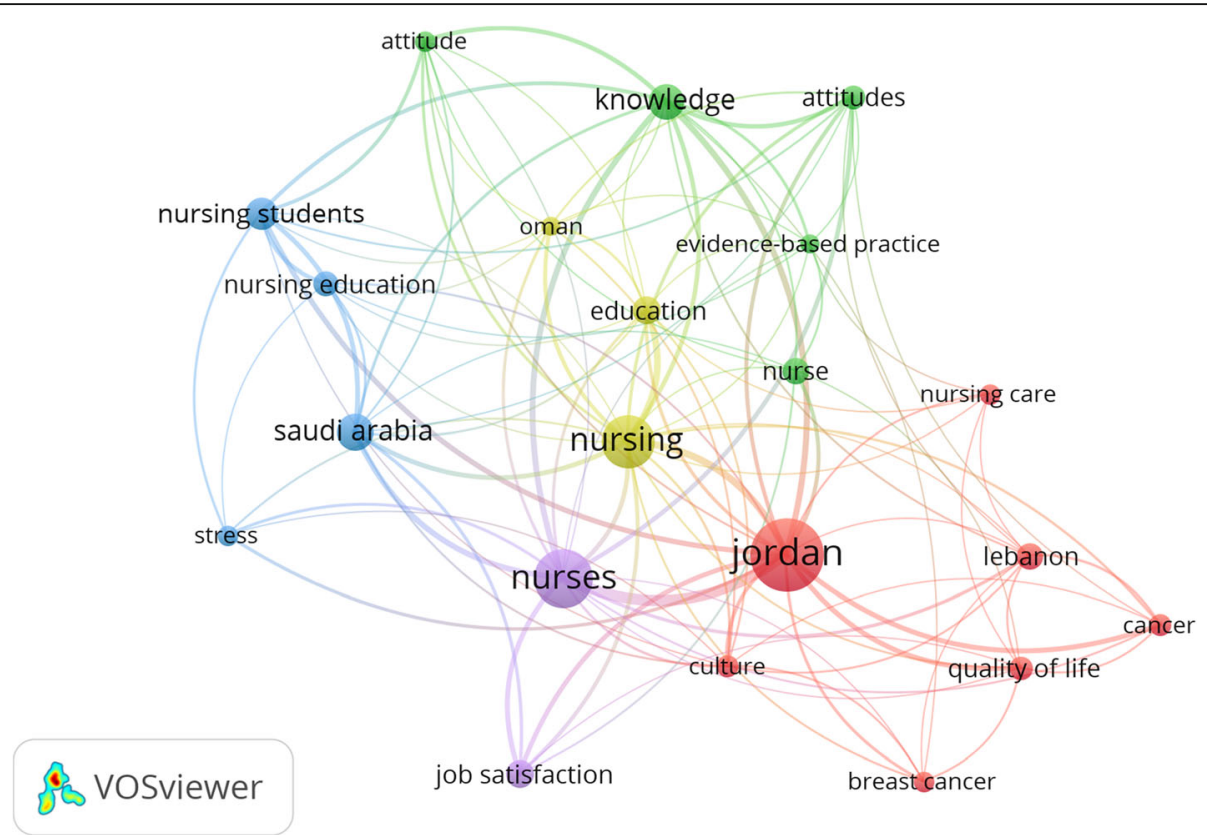

Fig. 1 Most frequent author keywords encountered in the retrieved documents. Larger node size indicates higher frequency of occurrence

of midwifery in improving the quality of healthcare [47]. The Arab researchers who participated in this article were from Palestine and had public health affiliation. The 10 most cited articles were published in nine different journals (Table 1). The topics discussed in these documents were diverse but mainly include topics related to non-communicable diseases and nursing education.

\section{Annual growth of publications}

Research output was steady and low up to year 2005 followed by a noticeable upsurge (Fig. 2). The total number of documents published in the last five years of the study period was $1663(56.7 \%)$. The number of documents increased by over than three-fold in 2017 relative to that in 2008.

\section{The 10 most active countries}

Jordan was the most active Arab country in nursing and midwifery research followed by Saudi Arabia, Egypt, and Lebanon. Researchers from Jordan contributed to over than one third $(1023 ; 34.9 \%)$ of the retrieved documents (Table 2). When research output was standardized by GDP per capita, Jordan also ranked first with 250.2 publications per GDP per capita followed by Egypt and Lebanon. Qualitatively, Lebanon ranked first in the percentage of documents published in high rank (first quartile $=\mathrm{Q} 1$ ) journals followed by Qatar and Jordan. In total, $742(25.3 \%)$ of the retrieved documents were published in Q1 journals. When data were ranked based on $h$-index, Jordan ranked first followed by Lebanon and Kuwait.

\section{International collaboration}

Analysis of international collaboration showed that United Arab Emirates ranked first in the percentage of publications (67.4\%) with international authors. Qatar and Iraq ranked second and third in international collaboration. Figure 3 is a visualization of international collaboration in nursing research. The location of the USA in the map's center indicated active research collaboration between the USA and many Arab countries. Based on the thickness of the connecting line, the strongest research collaboration was between the USA and Jordan (link strength $=200$ ), the USA and KSA (link strength = 85 ), the USA and Lebanon (link strength $=84$ ), Jordan and KSA (link strength $=82$ ), Jordan and Australia (link strength $=67$ ), and KSA with Egypt (link strength $=66$ ).

\section{The 10 most active journals}

Analysis of the retrieved documents showed that Life Science Journal ranked first $(158,5.4 \%)$ in publishing documents from Arab countries followed by International Nursing review (72; $2.5 \%)$ and International Journal of Nursing Practice (66; 2.2\%) (Table 3). Approximately $29 \%$ of documents produced by Egyptian nursing scholars were published in Life Science Journal. The Jordanian scholars authored the majority (93\%) of nursing documents published in the Jordan Medical Journal. The Saudi Medical Journal (SMJ) was one of the active journals. The $S M J$ is based in Saudi Arabia and Saudi scholars were the most active researchers in publishing in this journal. 
Table 1 Top 10 cited articles in nursing and midwifery field published from Arab countries (1900-2017)

\begin{tabular}{|c|c|c|c|c|c|c|c|}
\hline Title & Year & Source title & $\begin{array}{l}\text { Cited } \\
\text { by }\end{array}$ & $\begin{array}{l}\text { Document } \\
\text { Type }\end{array}$ & $\begin{array}{l}\text { Country affiliation of the } \\
\text { corresponding author }\end{array}$ & $\begin{array}{l}\text { Arab country } \\
\text { participating } \\
\text { in the study }\end{array}$ & $\begin{array}{l}\text { Is the corresponding } \\
\text { author affiliated with } \\
\text { a school of nursing? }\end{array}$ \\
\hline $\begin{array}{l}\text { Pain in elderly people with } \\
\text { severe dementia: A } \\
\text { systematic review of } \\
\text { behavioural pain assessment } \\
\text { tools [46] }\end{array}$ & 2006 & BMC Geriatrics & 305 & Review & The Netherlands & Lebanon & Yes \\
\hline $\begin{array}{l}\text { Midwifery and quality care: } \\
\text { Findings from a new } \\
\text { evidence-informed framework } \\
\text { for maternal and newborn care [47] }\end{array}$ & 2014 & The Lancet & 199 & Review & UK & Palestine & Yes \\
\hline $\begin{array}{l}\text { Job stress, job performance, } \\
\text { and social support among } \\
\text { hospital nurses [48] }\end{array}$ & 2004 & $\begin{array}{l}\text { Journal of Nursing } \\
\text { Scholarship }\end{array}$ & 164 & Review & Jordan & Jordan & Yes \\
\hline $\begin{array}{l}\text { Factors associated with poor } \\
\text { glycemic control among } \\
\text { patients with Type } 2 \text { diabetes [49] }\end{array}$ & 2010 & $\begin{array}{l}\text { Journal of Diabetes } \\
\text { and its Complications }\end{array}$ & 131 & Article & Jordan & Jordan & Yes \\
\hline $\begin{array}{l}\text { Evaluating the degree of difficulty } \\
\text { of laparoscopic colorectal } \\
\text { surgery [50] }\end{array}$ & 2008 & Archives of Surgery & 128 & Article & Lebanon & Lebanon & No \\
\hline $\begin{array}{l}\text { Critical thinking in nursing } \\
\text { education: Literature review [51] }\end{array}$ & 2002 & $\begin{array}{l}\text { International Journal } \\
\text { of Nursing Practice }\end{array}$ & 125 & Article & Saudi Arabia & Saudi Arabia & Yes \\
\hline $\begin{array}{l}\text { Prevalence of diabetes mellitus } \\
\text { and its complications in a } \\
\text { population-based sample in } \\
\text { Al Ain, United Arab Emirates [52] }\end{array}$ & 2007 & $\begin{array}{l}\text { Diabetes Research } \\
\text { and Clinical Practice }\end{array}$ & 107 & Article & UAE & UAE & No \\
\hline $\begin{array}{l}\text { Factors associated with breast } \\
\text { self-examination among } \\
\text { Jordanian women [53] }\end{array}$ & 2002 & $\begin{array}{l}\text { Public Health } \\
\text { Nursing }\end{array}$ & 93 & Article & Jordan & Jordan & Yes \\
\hline $\begin{array}{l}\text { Lifetime prevalence of mental } \\
\text { disorders in Lebanon: First onset, } \\
\text { treatment, and exposure to } \\
\text { war [54] }\end{array}$ & 2008 & PLoS Medicine & 88 & Article & Lebanon & Lebanon & No \\
\hline $\begin{array}{l}\text { IMPaCCT: Standards for paediatric } \\
\text { palliative care in Europe [55] }\end{array}$ & 2007 & $\begin{array}{l}\text { European Journal of } \\
\text { Palliative Care }\end{array}$ & 85 & Article & UK & Lebanon & Yes \\
\hline
\end{tabular}

UAE United Arab Emirates

\section{Authorship analysis}

In total, 10,572authors participated in publishing the retrieved documents, giving an average of 3.6 authors per article and a median of three. There were 446 (15.2\%) single-authored publications.

\section{Ten most active institutions}

Quantitative analysis showed that the University of Jordan ranked first $(339 ; 11.6 \%)$ followed by the Jordan University of Science and Technology (299; 10.2\%) and American University of Beirut (252; 8.6\%). The ten most active list of institutions included five institutions in Jordan, one in Lebanon, one in Kuwait, one in Egypt, and one in Saudi Arabia (Table 4). No significant correlation was found between nursing research output and Webometrics or QS University ranking of the ten most active institutions. When data were stratified by percentage of documents published in Q1,the American University of Beirut ranked first with approximately over one third of its documents being published in Q1 journals followed by King Saud University and Jordan University of Science and Technology.

\section{Discussion}

In the current study, research activity on nursing and midwifery in Arab countries was assessed and analyzed. The study showed low nursing research activity and research collaboration in Arab countries. In the past two decades, there was an increase in the number of researchers and the number of nursing faculties in Arab countries which participated in the growth of nursing and midwifery publications [57, 58]. For example, in Jordan, at least nine governmental and nongovernmental faculties of nursing are running. Similar situation exists in KSA and Egypt. A second potential reason for the upsurge in the number of publications is research collaboration. Several publications resulted from collaboration between researchers in Arab 


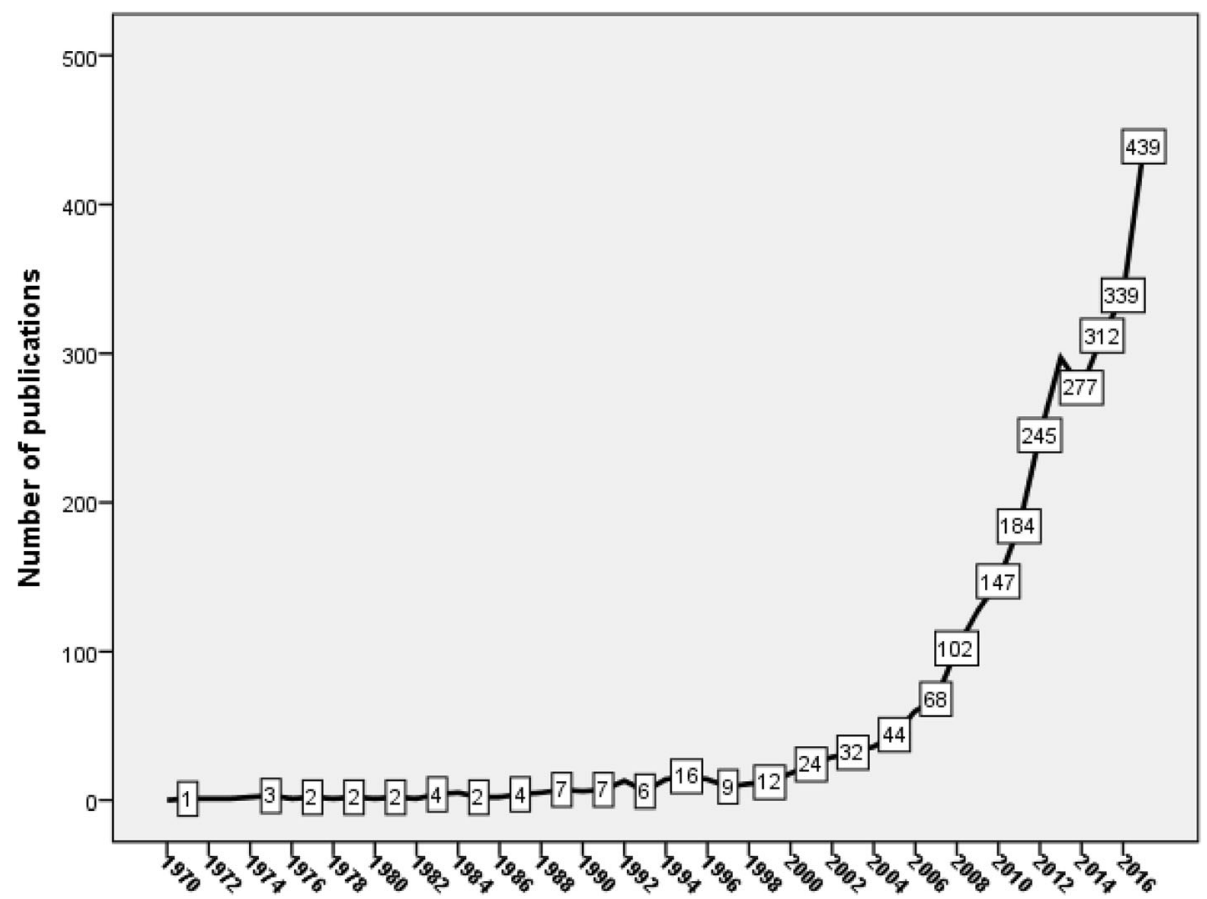

Fig. 2 Annual growth of publications in nursing and midwifery from Arab countries

countries with their mentors or colleagues or collaborators in developed countries [59-61]. The third potential reason is the academic pressure and competition which made researchers struggle to be promoted or get a tenure. In most Arab countries, academic promotion is based on the number and quality of publications. This is a strong driving force for competition among academics in various institutions to publish for tenure and promotion purposes. Finally, governments, health policy makers, international health organizations, and patients' demand for better healthcare quality [62-67] are also potential reasons for faculties of nursing to excel and adopt international standards in nursing education, practice and research. Recently, many academic institutions in Arab countries became aware of the importance of research component in regional and international university ranking systems. This was a major driving force for some universities in Arab region to give financial incentives to researchers based on their research activity. Furthermore, more funding became available from universities to encourage researchers to publish. Unfortunately, no data are available concerning the annual

Table 2 Ten most active Arab countries in nursing and midwifery research field

\begin{tabular}{|c|c|c|c|c|c|c|c|c|c|}
\hline Country & $\begin{array}{l}\text { Frequency } \\
N=2935\end{array}$ & $\%$ & $\begin{array}{l}\text { GDP per capita } \\
\left({ }^{\mathrm{a}} 1000\right)^{\mathrm{a}}\end{array}$ & $\begin{array}{l}\text { Number of publications per } \\
\text { GDP per capita }\end{array}$ & $\begin{array}{l}h \text {-index of the } \\
\text { publications }\end{array}$ & $\begin{array}{l}\text { Number of publications } \\
\text { with international authors }\end{array}$ & $\%$ & $\begin{array}{l}\text { Number of } \\
\text { publications in } \\
\text { Q1 Journals }\end{array}$ & $\%$ \\
\hline Jordan & 1023 & 34.9 & 4.088 & 250.2 & 34 & 478 & 46.7 & 293 & 28.6 \\
\hline Saudi Arabia & 615 & 21.0 & 20.29 & 30.3 & 25 & 363 & 59 & 142 & 23.1 \\
\hline Egypt & 464 & 15.8 & 3.478 & 133.4 & 22 & 244 & 52.6 & 68 & 14.7 \\
\hline Lebanon & 315 & 10.7 & 8.25 & 38.2 & 27 & 196 & 62.3 & 112 & 35.5 \\
\hline Oman & 153 & 5.2 & 14.981 & 10.2 & 12 & 90 & 58.9 & 36 & 23.5 \\
\hline Iraq & 137 & 4.7 & 4.61 & 29.7 & 17 & 83 & 60.9 & 10 & 7.3 \\
\hline Kuwait & 136 & 4.6 & 27.359 & 5.0 & 27 & 50 & 37 & 31 & 22.8 \\
\hline $\begin{array}{l}\text { United Arab } \\
\text { Emirates }\end{array}$ & 124 & 4.2 & 37.622 & 3.3 & 14 & 84 & 67.4 & 32 & 25.8 \\
\hline Qatar & 118 & 4.0 & 59.324 & 2.0 & 15 & 79 & 67.1 & 41 & 34.7 \\
\hline Palestine & 64 & 2.2 & 2.943 & 21.7 & 12 & 17 & 27.3 & 14 & 21.9 \\
\hline
\end{tabular}

aGross Domestic Product (at purchasing power parity) per capita obtained from World Bank [56] 


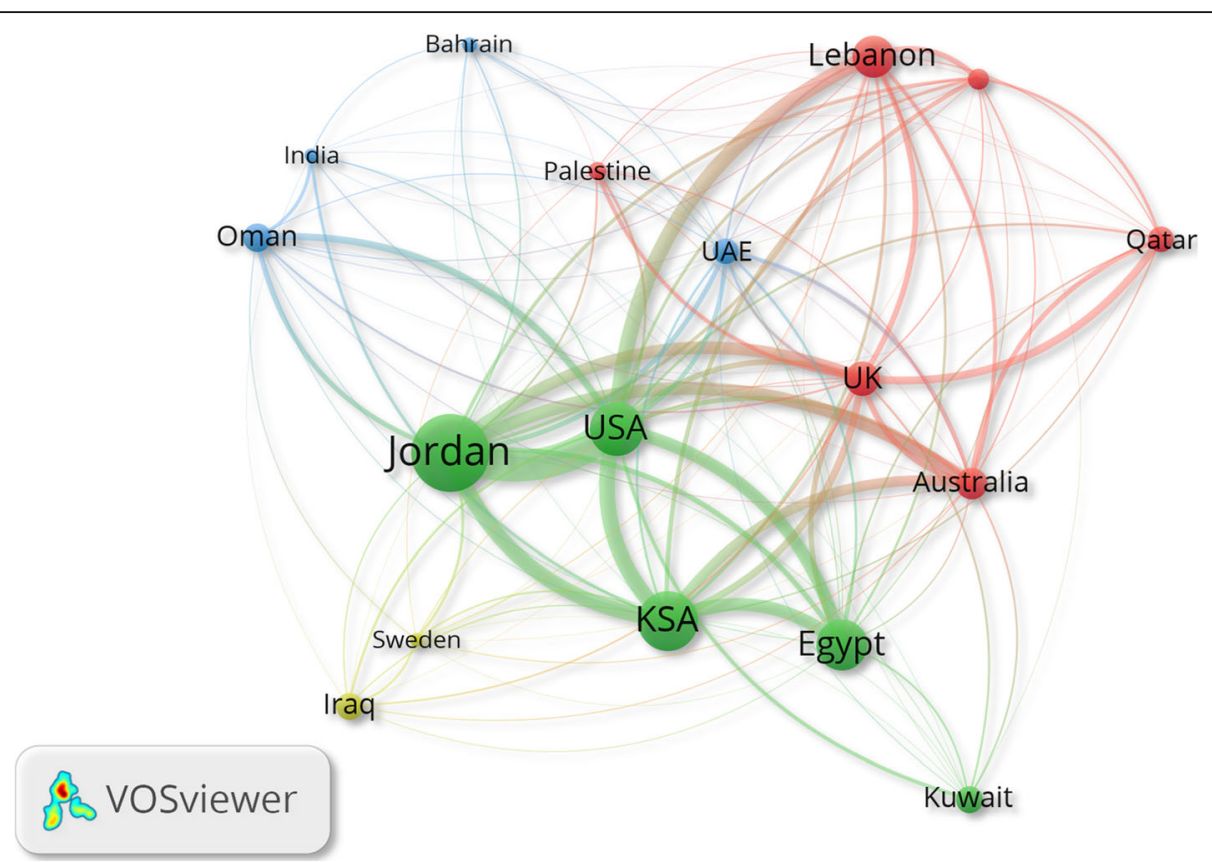

Fig. 3 International collaboration in nursing and midwifery research in Arab countries.The thickness of the connecting line between any two countries in the collaboration map is indicative of the strength of collaboration

volume of financial support for research activity from most active Arab universities. Therefore, correlation between funding and volume of publications from Arab universities remain an intuitive one.

The current study showed that the mean number of citations per article and the $h$-index of the retrieved documents were low when compared to other fields [6870]. This was unsurprising given the fact that research in this field is a relatively recent. Most documents published from Arab countries in the nursing and midwifery field are of local or regional interest. Therefore, it is difficult to attract a high number of citations from international authors [71]. A third potential reason for the low mean number of citations is the lack of a nursing and midwifery journal published from the Arab region. Such a journal will create a comprehensive database for Arab scholars, which will increase the visibility of publications and citations. The low number of citations, $h$ index, and the low percentage of documents published in Q1 journals indicate modest quality of publications from Arab countries. The current study showed limited number randomized clinical trials (RCTs) in the retrieved literature. Arab countries are still behind in this type of studies because of cultural and legal issues [72, 73]. Not all Arab countries have laws that support the implementation of RCT and other types of experimental

Table 3 Ten most active journals in publishing nursing and midwifery field from researchers in Arab countries

\begin{tabular}{|c|c|c|c|c|c|}
\hline Journal & $\begin{array}{l}\text { Frequency } \\
\mathrm{N}=2935\end{array}$ & $\%$ & $\begin{array}{l}\text { Country publishing } \\
\text { the journal }\end{array}$ & $\begin{array}{l}\text { IF } \\
\text { Thompson Reuters }\end{array}$ & $\begin{array}{l}\text { Arab country with the highest } \\
\text { percentage of publication } \\
\text { in the journal }\end{array}$ \\
\hline Life Science Journal & 158 & 5.4 & China & - & Egypt \\
\hline International Nursing Review & 72 & 2.5 & UK & 1.517 & Jordan \\
\hline International Journal Of Nursing Practice & 66 & 2.2 & UK & 1.018 & Jordan \\
\hline Eastern Mediterranean Health Journal & 64 & 2.2 & Switzerland (WHO) & 0.663 & Egypt \\
\hline Journal Of Advanced Nursing & 51 & 1.7 & UK & 1.998 & Jordan \\
\hline Journal Of Clinical Nursing & 51 & 1.7 & UK & 1.214 & Jordan \\
\hline Saudi Medical Journal & 50 & 1.7 & Saudi Arabia & 0.73 & Saudi Arabia \\
\hline International Journal Of Nursing Studies & 48 & 1.6 & UK & 3.755 & Jordan \\
\hline Jordan Medical Journal & 46 & 1.6 & Jordan & - & Jordan \\
\hline Nurse Education Today & 42 & 1.4 & UK & 2.533 & Jordan \\
\hline
\end{tabular}


Table 4 Ten most active institutions in the nursing and midwifery field

\begin{tabular}{|c|c|c|c|c|c|c|c|c|}
\hline Institution & $\begin{array}{l}\text { Frequency } \\
\mathrm{N}=2935\end{array}$ & $\%$ & $\begin{array}{l}\text { Number of publications } \\
\text { in Q1 Journals }\end{array}$ & $\%$ & $\begin{array}{l}\text { Country } \\
\text { affiliation }\end{array}$ & $\begin{array}{l}\text { h-index of the } \\
\text { publications }\end{array}$ & $\begin{array}{l}\text { Webometrics University } \\
\text { ranking in Arab world }\end{array}$ & $\begin{array}{l}\text { QS University } \\
\text { Ranking }\end{array}$ \\
\hline The University of Jordan & 339 & 11.6 & 87 & 25.7 & Jordan & 24 & 10 & 9 \\
\hline $\begin{array}{l}\text { Jordan University of Science } \\
\text { and Technology }\end{array}$ & 299 & 10.2 & 91 & 30.4 & Jordan & 27 & 17 & 14 \\
\hline American University of Beirut & 252 & 8.0 & 93 & 36.9 & Lebanon & 28 & 5 & 1 \\
\hline Hashemite University & 186 & 6.3 & 44 & 23.7 & Jordan & 19 & 33 & 48 \\
\hline Alexandria University & 122 & 4.2 & 20 & 16.4 & Egypt & 16 & 9 & 15 \\
\hline King Saud University & 113 & 3.9 & 37 & 32.7 & $\begin{array}{l}\text { Saudi } \\
\text { Arabia }\end{array}$ & 19 & 1 & 3 \\
\hline Sultan Qaboos University & 111 & 3.8 & 29 & 26.1 & Oman & 25 & 44 & 10 \\
\hline University of Kuwait & 99 & 3.4 & 19 & 19.2 & Kuwait & 25 & 16 & 19 \\
\hline Al Al-Bayt University & 96 & 3.3 & 28 & 29.2 & Jordan & 13 & 78 & - \\
\hline University of Mutah & 85 & 2.9 & 25 & 29.4 & Jordan & 11 & 88 & - \\
\hline
\end{tabular}

studies that involve humans [73-75]. Patients in Arab countries might not be willing to participate or volunteer in such studies. Patients in Arab countries lack the awareness of such type of studies and might think negatively and suspiciously about such type of studies $[72,74]$. One final point is that researchers in Arab countries might lack the expertise or adequate funding to carry out such studies given that RCT require team work with diverse experiences as well as adequate funding to cover all aspects of the trials. A recently published Delphi survey about nursing research priorities in Middle Eastern region concluded that "critical research priorities should focus on population-based health topics" [76].

The current study showed that nursing and midwifery research in some Arab countries has made noticeable progress while research in other Arab countries is still lagging and even "neglected". The Arab Gulf countries (Oman, Qatar, UAE, Bahrain, KSA, and Kuwait)with high income and research funding are present in the list of active countries. In the past three decades, all Arab Gulf countries established various medical colleges including ones for nursing and allied health sciences [77, 78]. Furthermore, most institutions in Arab Gulf countries had successfully recruited researchers who helped improve nursing research output from these countries [79]. Despite the huge budget available for medical education and research in Arab Gulf countries, both Jordan and Lebanon made an outstanding quantitative and qualitative contribution to nursing and midwifery research that surpassed that of Arab Gulf countries. Medical and nursing education in Lebanon started as early as 1900 s while that in Jordan is relatively recent. It seems that conflict in the Middle East created a high demand for medical services in both Jordan and
Lebanon, which prompted greater planning for nursing education and research.

\section{Limitations}

Bibliometric analysis is confounded by the absence of a comprehensive database that includes all documents published in all peer-reviewed journals. Despite this, Scopus remains an ideal database to carry out such studies because it is the largest of all available databases. In bibliometric analyses, the research findings depend on the retrieved documents, which in turn depend on the implemented search strategy. False-negative results are still a possibility that might cause an underestimation of the research output and citation of a particular author, institution, country, or journal. Therefore, the results in this study need to be interpreted based on the search strategy and the database used. Finally, self-citation might affect the h-index value for authors, institutions, and countries. Therefore, the value of $h$-index is sometimes misleading when self-citation is included in the analysis.

\section{Conclusions}

Nursing and midwifery research in Arab countries is part of the overall medical research in Arab countries, which has been lagging relative to other countries [8089]. However, nursing and midwifery research in Arab countries is on the rise and expected to advance nursing practice and healthcare services in Arab countries. Researchers in active Arab countries such as Jordan, Lebanon, and Gulf countries need to seek high quality publications to contribute positively to the global advancement of nursing profession. Researchers in Arab countries need to launch RCTs to contribute to evidence-based nursing practice. It is also important that researchers in Arab countries start focusing on nursing 
topics in the field of infectious diseases and potential role of nursing staff in minimizing the burden of such diseases. Authors of the current study recommend stronger research collaboration between active Arab countries and those lagging in nursing research. Nursing conferences in Arab world need to be encouraged to help better communication among all those in the field.

\section{Additional files}

Additional file 1: Keywords and search methodology used in Scopus to retrieve related documents. Supplement 1 included search query and a step - by - step guide to retrieve the required data from Scopus database. (DOC $39 \mathrm{~kb}$ )

Additional file 2: List of active researchers used to test validity of the search strategy. Supplement 2 included a list of active authors with their research output obtained by two different methods was compared to test for the validity of the search strategy. (DOC $34 \mathrm{~kb}$ )

\section{Abbreviations}

AUB: American University of Beirut; EMRO: Eastern Mediterranean Region; GDP: Gross Domestic Product; GDP: Gross Domestic Product; KSA: Kingdom of Saudi Arabia; Q: Quartile; RCT: Randomized Clinical Trial; SJR: SCImago Journal Rank; SMJ: Saudi Medical Journal; UAE: United Arab Emirates; UK: United Kingdom; USA: United States of America; WHO: World Health Organization

\section{Acknowledgements}

The authors would like to thank An-Najah National University for giving us the opportunity to access most recent information sources.

\section{Authors' contributions}

All authors read and approved the final version of the manuscript. WS started the idea and designed the methodology; SA and SZ did the data analysis and graphics and data interpretation; A.S wrote the manuscript and did the literature review; $\mathrm{HH}$ helped in developing the methodology, reviewed the manuscript, and enriched the discussion.

\section{Funding}

None.

\section{Availability of data and materials}

The datasets used and/or analysed during the current study are available from the corresponding author on reasonable request.

\section{Ethics approval and consent to participate}

Not applicable.

IRB at An-Najah National University, Palestine requires no approval for bibliometric studies.

\section{Consent for publication}

Not applicable.

\section{Competing interests}

The authors declare that they have no competing interests. However, Prof. $\mathrm{H}$. $\mathrm{H}$, one of the co-authors of the manuscript, ranked one of the top 10 active authors in the field of nursing. Prof. $\mathrm{H}$. $\mathrm{H}$ did not participate in the analysis and had no influence on the results.

\section{Author details}

'Department of Biomedical Sciences, College of Medicine and Health Sciences, An-Najah National University, Nablus, Palestine. ${ }^{2}$ Hariri School of Nursing, American University of Beirut, Beirut, Lebanon. ${ }^{3}$ Department of Pharmacy, College of Medicine and Health Sciences, An-Najah National University, Nablus, Palestine.
Received: 23 May 2018 Accepted: 20 May 2019

Published online: 28 May 2019

\section{References}

1. Al-Momani MM, Al-Barmawi MA, Al-Hadid L, Aljabery A. Developing a tool that explores factors influencing the adoption of evidence-based principles in nursing practice in Jordan. Appl Nurs Res. 2016:32:122-7.

2. Cruz JP, Colet PC, Alquwez N, Alqubeilat H, Bashtawi MA, Ahmed EA, Cruz CP. Evidence-based practice beliefs and implementation among the nursing bridge program students of a Saudi University. Int J Health Sci (Qassim). 2016:10(3):405-14.

3. Ez elarab HS, El Salam SA, Behalik SG, Eltayeb HE. Nurses, practice, knowledge and attitude towards evidence-based practice at Yanbu general hospital -kingdom of Saudi Arabia. Life Sci J. 2012;9(3):1062-71.

4. Hamaideh $\mathrm{SH}$. Sources of knowledge and barriers of implementing evidence-based practice among mental health nurses in Saudi Arabia. Perspect Psychiatr Care. 2017;53(3):190-8.

5. Salem O. Evidence based nursing practice inside and outside middle east. World Applied Sci J. 2013;27(7):803-10.

6. Polit DF, Beck $C T$. Nursing research: generating and assessing evidence for nursing practice. Philadelphia, PA: Lippincott Williams \& Wilkins; 2008.

7. Ellenbecker $\mathrm{CH}$, Edward J. Conducting nursing research to advance and inform health policy. Policy Polit Nurs Pract. 2016;17(4):208-17.

8. Sweileh WM. Bibliometric analysis of peer-reviewed literature in transgender health (1900 - 2017). BMC Int Health Hum Rights. 2018;18(1):16.

9. Sweileh WM. Global research trends of World Health Organization's top eight emerging pathogens. Glob Health. 2017;13(1):9.

10. Muller AM, Maher CA, Vandelanotte C, Hingle M, Middelweerd A, Lopez ML, DeSmet A, Short CE, Nathan N, Hutchesson MJ, et al. Physical activity, sedentary behavior, and diet-related eHealth and mHealth research: bibliometric analysis. J Med Internet Res. 2018:20(4):e122.

11. Sweileh WM. A bibliometric analysis of health-related literature on natural disasters from 1900 to 2017 Health Res Policy Syst. 2019;17(1):18. https://doi. org/10.1186/s12961-019-0418-1

12. Singh S, Pandita R. Measurement of global nursing research output: a bibliometric study (1996-2015). J Inf Sci Theory Pract. 2018;6(1):31-44.

13. Carter-Templeton H, Frazier RM, Wu L, HW T. Robotics in nursing: a bibliometric analysis. J Nurs Scholarsh. 2018;50(6):582-9.

14. Estabrooks CA, Winther C, Derksen L. Mapping the field: a bibliometric analysis of the research utilization literature in nursing. Nurs Res. 2004;53(5): 293-303.

15. Alfonzo P, Sakaraida T, Hasting-Tolsma M. Bibliometrics: visualizing the impact of nursing research. Online J Nurs Inform. 2014;18(1).

16. World Health Organization (WHO). World Health Organization. (2016c). WHO progress report on nursing and midwifery, 2013-2015. 2016 [cited 2018 December 24]; Available from: https://www.who.int/hrh/nursing_midwifery/ nursing-midwifery_report_13-15.pdf?ua=1

17. Elsevier. Scopus. 2018 [cited 2018 December 24]; Available from: https:// www.elsevier.com/solutions/scopus

18. Falagas ME, Pitsouni El, Malietzis GA, Pappas G. Comparison of PubMed, Scopus, web of science, and Google scholar: strengths and weaknesses. FASEB J. 2008;22(2):338-42.

19. Wallin JA. Bibliometric methods: pitfalls and possibilities. Basic Clin Pharmacol Toxicol. 2005;97(5):261-75

20. Van Raan AF. Advances in bibliometric analysis: research performance assessment and science mapping. In: Blockmans W, Engwall L, Weaire D, editors. Bibliometrics Use and Abuse in the Review of Research Performance. London, UK: Portland Press; 2014. p. 17-28.

21. Peters MD, Godfrey CM, Khalil H, Mclnerney P, Parker D, Soares CB. Guidance for conducting systematic scoping reviews. Int J Evid Based Healthc. 2015:13(3):141-6.

22. Moller AM, Myles PS. What makes a good systematic review and metaanalysis? Br J Anaesth. 2016:117(4):428-30.

23. Grant MJ, Booth A. A typology of reviews: an analysis of 14 review types and associated methodologies. Health Inf Libr J. 2009;26(2):91-108.

24. Levac D, Colquhoun H, O'Brien KK. Scoping studies: advancing the methodology. Implement Sci. 2010;5(1):69.

25. Findlay AM. The Arab world. London: Routledge; 2002

26. Zyoud SH, Waring WS, Sweileh WM, Al-Jabi SW. Global research trends in Lithium toxicity from 1913 to 2015: a bibliometric analysis. Basic Clin Pharmacol Toxicol. 2017;121(1):67-73. 
27. Zyoud SH, Waring WS, Al-Jabi SW, Sweileh WM. Global cocaine intoxication research trends during 1975-2015: a bibliometric analysis of web of science publications. Subst Abuse Treat Prev Policy. 2017;12(1):6.

28. Sweileh WM, Al-Jabi SW, Zyoud SH, Sawalha AF, Abu-Taha AS. Global research output in antimicrobial resistance among uropathogens: a bibliometric analysis (2002-2016). J Glob Antimicrob Resist. 2018;13:104-14.

29. Sweileh WM, Al-Jabi SW, Sawalha AF, AbuTaha AS, Zyoud SH: Bibliometric analysis of worldwide publications on antimalarial drug resistance (20062015). Malar Res Treat 2017, 2017:6429410.

30. Sweileh WM, AbuTaha AS, Sawalha AF, Al-Khalil S, Al-Jabi SW, Zyoud SH. Bibliometric analysis of worldwide publications on multi-, extensively, and totally drug - resistant tuberculosis (2006-2015). Multidiscip Respir Med. 2016;11:45

31. Gearing RE, Mian IA, Barber J, Ickowicz A. A methodology for conducting retrospective chart review research in child and adolescent psychiatry. J Can Acad Child Adolesc Psychiatry. 2006;15(3):126-34.

32. Kimberlin $\mathrm{CL}$, Winterstein $\mathrm{AG}$. Validity and reliability of measurement instruments used in research. Am J Health Syst Pharm. 2008;65(23):2276-84.

33. Banks NJ. Designing medical record abstraction forms. Int J Qual Health Care. 1998;10(2):163-7.

34. Allison JJ, Wall TC, Spettell CM, Calhoun J, Fargason CA Jr, Kobylinski RW, Farmer R, Kiefe C. The art and science of chart review. Jt Comm J Qual Improv. 2000;26(3):115-36.

35. Hallgren K. Computing inter-rater reliability for observational data: an overview and tutorial. Tutor Quant Methods Psychol. 2003;8(1):23-34.

36. The World Bank. Countries and Economies. 2018 [cited 2018 April 05]; Available from: https://data.worldbank.org/country/

37. van Eck NJ, Waltman L. Software survey: VOSviewer, a computer program for bibliometric mapping. Scientometrics. 2010;84(2):523-38.

38. Van Eck NJ, Waltman L. VOSviwer. 2018 [cited 2018 May 12, 2018]; Available from: http://www.vosviewer.com/

39. van Eck NJ, Waltman L. VOSviewer manual. Leiden, the Nederlands: Univeristeit Leiden; 2013

40. Cucchetti A, Mazzotti F, Pellegrini S, Cescon M, Maroni L, Ercolani G, Pinna $A D$. The use of the Hirsch index in benchmarking hepatic surgery research. Am J Surg. 2013;206(4):560-6.

41. Engel A. The Hirsch index. Color Dis. 2013;15(1):1.

42. Saleem $T$. The Hirsch index - a play on numbers or a true appraisal of academic output? Int Arch Med. 2011:4:25.

43. Opthof T, Wilde AA. The Hirsch-index: a simple, new tool for the assessment of scientific output of individual scientists: the case of Dutch professors in clinical cardiology. Neth Heart J. 2009;17(4):145-54.

44. Ivanova OA. The Hirsch index is a new criterion for evaluation of scientific activity. Biomed Khim. 2008;54(1):5-11.

45. SCImago. SCImago Journal and Country Rank (SJR). 2018 [cited 2018 December 24]; Available from: https://www.scimagojr.com/

46. Zwakhalen SM, Hamers JP, Abu-Saad HH, Berger MP. Pain in elderly people with severe dementia: a systematic review of behavioural pain assessment tools. BMC Geriatr. 2006;6:3.

47. Renfrew MJ, McFadden A, Bastos MH, Campbell J, Channon AA, Cheung NF, Silva DR, Downe S, Kennedy HP, Malata A, et al. Midwifery and quality care: findings from a new evidence-informed framework for maternal and newborn care. Lancet. 2014;384(9948):1129-45.

48. AbuAlRub RF. Job stress, job performance, and social support among hospital nurses. J Nurs Scholarsh. 2004;36(1):73-8.

49. Khattab M, Khader YS, Al-Khawaldeh A, Ajlouni K. Factors associated with poor glycemic control among patients with type 2 diabetes. J Diabetes Complicat. 2010;24(2):84-9.

50. Jamali FR, Soweid AM, Dimassi H, Bailey C, Leroy J, Marescaux J. Evaluating the degree of difficulty of laparoscopic colorectal surgery. Arch Surg. 2008; 143(8):762-7 discussion 768.

51. Simpson E, Courtney M. Critical thinking in nursing education: literature review. Int J Nurs Pract. 2002;8(2):89-98.

52. Saadi H, Carruthers SG, Nagelkerke N, Al-Maskari F, Afandi B, Reed R, Lukic M, Nicholls MG, Kazam E, Algawi K, et al. Prevalence of diabetes mellitus and its complications in a population-based sample in Al Ain, United Arab Emirates. Diabetes Res Clin Pract. 2007;78(3):369-77.

53. Petro-Nustus W, Mikhail Bl. Factors associated with breast self-examination among jordanian women. Public Health Nurs. 2002;19(4):263-71.

54. Karam EG, Mneimneh ZN, Dimassi H, Fayyad JA, Karam AN, Nasser SC, Chatterji S, Kessler RC. Lifetime prevalence of mental disorders in Lebanon: first onset, treatment, and exposure to war. PLoS Med. 2008;5(4):e61.
55. Craig F, Abu-Saad Huijer H, Benini F, Kuttner L, Wood C, Feraris PC, Zernikow B. IMPaCCT: standards of paediatric palliative care. Schmerz. 2008; 22(4):401-8.

56. World Bank. GDP per capita, PPP (current international \$). 2017 [cited 2018 April 26, 2018]; Available from: https://data.worldbank.org/indicator/NY.GDP. PCAP.PP.CD?year_high_desc=true.

57. Zahran Z. Nurse education in Jordan: history and development. Int Nurs Rev. 2012;59(3):380-6.

58. Saifan AR, Safieh HA, Milbes R, Shibly R. Suggestions to close the gap in nursing education: nursing students' perspectives. Int J Adv Nurs Stud. 2015; $4(2): 62-8$

59. Doumit MA, El Saghir N, Abu-Saad Huijer H, Kelley JH, Nassar N. Living with breast cancer, a Lebanese experience. Eur J Oncol Nurs. 2010;14(1):42-8.

60. Marini SD, Hasman A, Huijer HA. Information technology for medication administration: assessing bedside readiness among nurses in Lebanon. Int J Evid Based Healthc. 2009;7(1):49-58.

61. van Bruchem-van de Scheur A, van der Arend A, van Wijmen F, Abu-Saad $\mathrm{HH}$, Ter Meulen R. Dutch nurses' attitudes towards euthanasia and physician-assisted suicide. Nurs Ethics. 2008;15(2):186-98.

62. Al-Yateem N, Rossiter RC, Robb WF, Slewa-Younan S. Mental health literacy of school nurses in the United Arab Emirates. Int J Ment Health Syst. 2018;12(1):6.

63. Amouri SE, O'Neill S. Leadership style and culturally competent care: nurse leaders' views of their practice in the multicultural care settings of the United Arab Emirates. Contemp Nurse. 2014;48(2):135-49.

64. Clerehan R, McCall L, McKenna L, Alshahrani K. Saudi Arabian nurses' experiences of studying masters degrees in Australia. Int Nurs Rev. 2012; 59(2):215-21.

65. Katvan E, Bartal N. The midwives ordinance of Palestine, 1929: historical perspectives and current lessons. Nurs Inq. 2010;17(2):165-72.

66. Wollin JA, Fairweather CT. Nursing education: a case study of a bachelor of science nursing programme in Abu Dhabi, United Arab Emirates. J Nurs Manag. 2012;20(1):20-7.

67. Younis MZ. Interview: comparative effectiveness research and challenges to healthcare reform in the Middle East and USA. J Comp Eff Res. 2013;2(3): 223-5.

68. Sweileh WM. Analysis of global research output on diabetes depression and suicide. Ann General Psychiatry. 2018;17:44.

69. Sweileh WM. Global research output on HIV/AIDS-related medication adherence from 1980 to 2017. BMC Health Serv Res. 2018;18(1):765.

70. Sweileh WM, Al-Jabi SW, Zyoud SH, Shraim NY, Anayah FMA, Sawalha AF, AbuTaha AS. Bibliometric analysis of global publications in medication adherence (1900-2017). Int J Pharm Pract. 2018; Epub ahead of print.

71. Gazni A, Didegah F. Investigating different types of research collaboration and citation impact: a case study of Harvard University's publications. Scientometrics. 2011;87(2):251-65.

72. Al-Lawati H, Al-Baimani K, Al-Zadjali M, Al-Obaidani N, Al-Kiyumi Z, Al-Khabor MK. Knowledge and attitudes towards clinical trial participation in Oman: a cross-sectional study. Sultan Qaboos Univ Med J. 2018;18(1):e54-60.

73. Nair SC, Al Marzooqi F, Al Khamiri A. Health Research, Regulations and Ethics in the United Arab Emirates. In: Research Ethics in the Arab Region. Springer; 2017. p. 255-66.

74. Nair SC, Ibrahim H, Celentano DD. Clinical trials in the Middle East and North Africa (MENA) Region: grandstanding or grandeur? Contemp Clin Trials. 2013;36(2):704-10.

75. Alahmad G, Al-Jumah M, Dierickx K. Review of national research ethics regulations and guidelines in middle eastern Arab countries. BMC Med Ethics. 2012;13(1):34.

76. Sun C, Dohrn J, Oweis A, Huijer HA, Abu-Moghli F, Dawani H, Ghazi C, Larson E. Delphi survey of clinical nursing and midwifery research priorities in the eastern Mediterranean region. J Nurs Scholarsh. 2017;49(2):223-35.

77. Hamdy H, Telmesani AW, Al Wardy N, Abdel-Khalek N, Carruthers G, Hassan F, Kassab S, Abu-Hijleh M, Al-Roomi K, O'Malley K, et al. Undergraduate medical education in the Gulf cooperation council: a multi-countries study (part 1). Med Teach. 2010;32(3):219-24.

78. Hamdy H, Telmesani AW, Wardy NA, Abdel-Khalek N, Carruthers G, Hassan F, Kassab S, Abu-Hijleh M, Al-Roomi K, O'Malley K, et al. Undergraduate medical education in the Gulf cooperation council: a multi-countries study (part 2). Med Teach. 2010;32(4):290-5.

79. Chouchane L, Mamtani R, Al-Thani MH, Al-Thani AA, Ameduri M, Sheikh Jl. Medical education and research environment in Qatar: a new epoch for translational research in the Middle East. J Transl Med. 2011;9(1):16. 
80. Al-Yateem N, Docherty C, Brenner M, Alhosany J, Altawil H, Al-Tamimi M. Research priorities for school nursing in the United Arab Emirates (UAE). J Sch Nurs. 2017;33(5):393-401.

81. McCreaddie M, Kuzemski D, Griffiths J, Sojka EM, Fielding M, Al Yateem N, Williams JJ. Developing nursing research in the United Arab Emirates: a narrative review. Int Nurs Rev. 2018;65(1):93-101.

82. Naja F, Shatila H, Meho L, Alameddine M, Haber S, Nasreddine L, Sibai AM, Hwalla N. Gaps and opportunities for nutrition research in relation to noncommunicable diseases in Arab countries: call for an informed research agenda. Nutr Res. 2017;47:1-12.

83. Abouchedid K, Abdelnour G. Faculty research productivity in six Arab countries. Int Rev Educ. 2015;61(5):673-90.

84. Bayoumy K, MacDonald R, Dargham SR, Arayssi T. Bibliometric analysis of rheumatology research in the Arab countries. BMC Res Notes. 2016;9(1):393.

85. Gul S, Nisa NT, Shah TA, Gupta S, Jan A, Ahmad S. Middle East: research productivity and performance across nations. Scientometrics. 2015;105(2): 1157-66.

86. Sweileh WM, Al-Jabi SW, Abuzanat A, Sawalha AF, AbuTaha AS, Ghanim MA, Zyoud SH. Assessment of research productivity of Arab countries in the field of infectious diseases using web of science database. Infect Dis Poverty. 2015:4(1):2.

87. Sweileh WM, Zyoud SH, Al-Jabi SW, Sawalha AF. Quantity and quality of obesity-related research in Arab countries: assessment and comparative analysis. Health Res Policy Syst. 2014;12(1):33.

88. Sweileh WM, Zyoud SH, Al-Jabi SW, Sawalha AF. Contribution of Arab countries to breast cancer research: comparison with non-Arab middle eastern countries. BMC Womens Health. 2015;15(1):25.

89. Zyoud SH, Al-Jabi SW, Sweileh WM, Awang R. A bibliometric analysis of toxicology research productivity in middle eastern Arab countries during a 10-year period (2003-2012). Health Res Policy Syst. 2014;12(1):4.

\section{Publisher's Note}

Springer Nature remains neutral with regard to jurisdictional claims in published maps and institutional affiliations.

Ready to submit your research? Choose BMC and benefit from:

- fast, convenient online submission

- thorough peer review by experienced researchers in your field

- rapid publication on acceptance

- support for research data, including large and complex data types

- gold Open Access which fosters wider collaboration and increased citations

- maximum visibility for your research: over $100 \mathrm{M}$ website views per year

At $\mathrm{BMC}$, research is always in progress.

Learn more biomedcentral.com/submissions 